\title{
Seven Years of MGNREGS: A Temporal Analysis of Employment Related Aspects in West Bengal, India
}

\author{
SarmisthaSaha \\ Department of Geography, Michael Madhusudan Memorial College, Durgapur,India \\ Research Scholar, JNU, New Delhi, India
}

\begin{abstract}
This paper tries to explore how MGNREGS, the most contemporary rural developmental scheme of rural India has implemented in the state of West Bengal on a temporal scale. Various employmentrelated aspects are discussed with their temporal variation and possible causes of these variations are explored with most contemporary journalistic explanations. This paper throws light on some critical issues of discussion with a concluding note of enhancement of success ratio with the fulfilment of promised employment days.
\end{abstract}

Keywords:, Demand-driven, Receive - demand ratio, Self target, Temporal Demand, Temporal Spread

\section{Introduction}

Mahatma Gandhi National Rural Employment Guarantee Scheme which was enacted in 2005 with a promise of 100 days of promised employment days in every financial year to per job demanding registered rural household, now covered seven long years of journey. MGNREGA became operational in West Bengal since February, 2006. The scope of the scheme and its ground reality has remained in the focus of discussion for geographers, economists and various social scientists. Still, there is a dearth of literatures focussing on the journey in the state of West Bengal. Discussion on the temporal scale of MGNREGS implementation is rare focussing this state. This paper tries to explore the temporal change in employment related aspects of MGNREGS implementation in West Bengal in last seven years.

MGNREGA became operational in West Bengal since February, 2006. For this, the study has adopted the methodologies of use of simple statistical techniques. Data source of the study refers to the website of the Ministry of Rural Development, www.nrega.nic.in .

TABLE.1.PHASE WISE COVERAGE OF MGNREGS IN RURAL WEST BENGAL

\begin{tabular}{|c|c|c|}
\hline PHASE-I DISTRICTS & PHASE-II DISTRICTS & PHASE-III DISTRICTS \\
\hline 24 Paraganas South & Cooch Behar & Howrah \\
\hline Bankura & Nadia & \\
\hline Birbhum & Bardhdhaman & \\
\hline DinajpurDakshin & Medinipur East & \\
\hline Dinajpur Uttar & North 24 Paraganas & \\
\hline Jalpaiguri & Hoogly & \\
\hline Maldah & Darjeeling & \\
\hline Medinipur West & & \\
\hline Murshidabad & & Total=2 \\
\hline Puruliya & Total=7 & \\
\hline Total=10 & & \\
\hline
\end{tabular}

Source:http://nrega.nic.in/MNREGA_Dist.pdf accessed on 06.12.2013

The Report on NREGA Survey conducted by Government of India states "The Act was notified in 200 rural districts in its first phase of implementation (with effect from $2^{\text {nd }}$ February 2006). In FY 2007-08, it was extended to an additional 130 rural districts. The remaining districts were notified under MGNREGA with effect from1 April 2008.Since2008, MGNREGA has covered the entire country with the exception of districts that have a hundred per cent urban population." Now MGNREGS is in operation in all rural parts ofWest Bengal. In its First phase, the scheme was implemented in $55.55 \%$ ofconstituting districts, in $2^{\text {nd }}$ phase it has covered $38.88 \%$ districts and rest $5.5 \%$ district was covered in third phase. 
II. Temporal Demand Trend Of MGNREGS Job In West Bengal

TABLE. 2. DEMAND TREND OF MGNREGS JOB IN WEST BENGAL

\begin{tabular}{|c|c|c|c|}
\hline YEAR & $\begin{array}{c}\text { NO.OF HOUSEHOLDS } \\
\text { DEMANDED } \\
\text { EMPLOYMENT }\end{array}$ & $\begin{array}{c}\text { NO.OF RURAL } \\
\text { HOUSEHOLDS }\end{array}$ & $\begin{array}{c}\text { \% OF RURAL HOUSEHOLDS } \\
\text { DEMANDED EMPLOYMENT }\end{array}$ \\
\hline $2006-2007$ & 3235360 & $1,11,61,870 * 1$ & 28.99 \\
\hline $2007-2008$ & 3919996 & $1,11,61,870$ & 27.11 \\
\hline $2008-2009$ & 3025854 & $1,11,61,870$ & 45.10 \\
\hline $2009-2010$ & 5034060 & $1,11,61,870$ & 39.61 \\
\hline $2010-2011$ & 4421189 & $1,11,61,870$ & 40.33 \\
\hline $2011-2012$ & 5532363 & $1,37,17,186 * 2$ & 42.44 \\
\hline $2012-2013$ & 5822214 & $1,37,17,186$ & \\
\hline
\end{tabular}

Source-www.nrega.nic.in

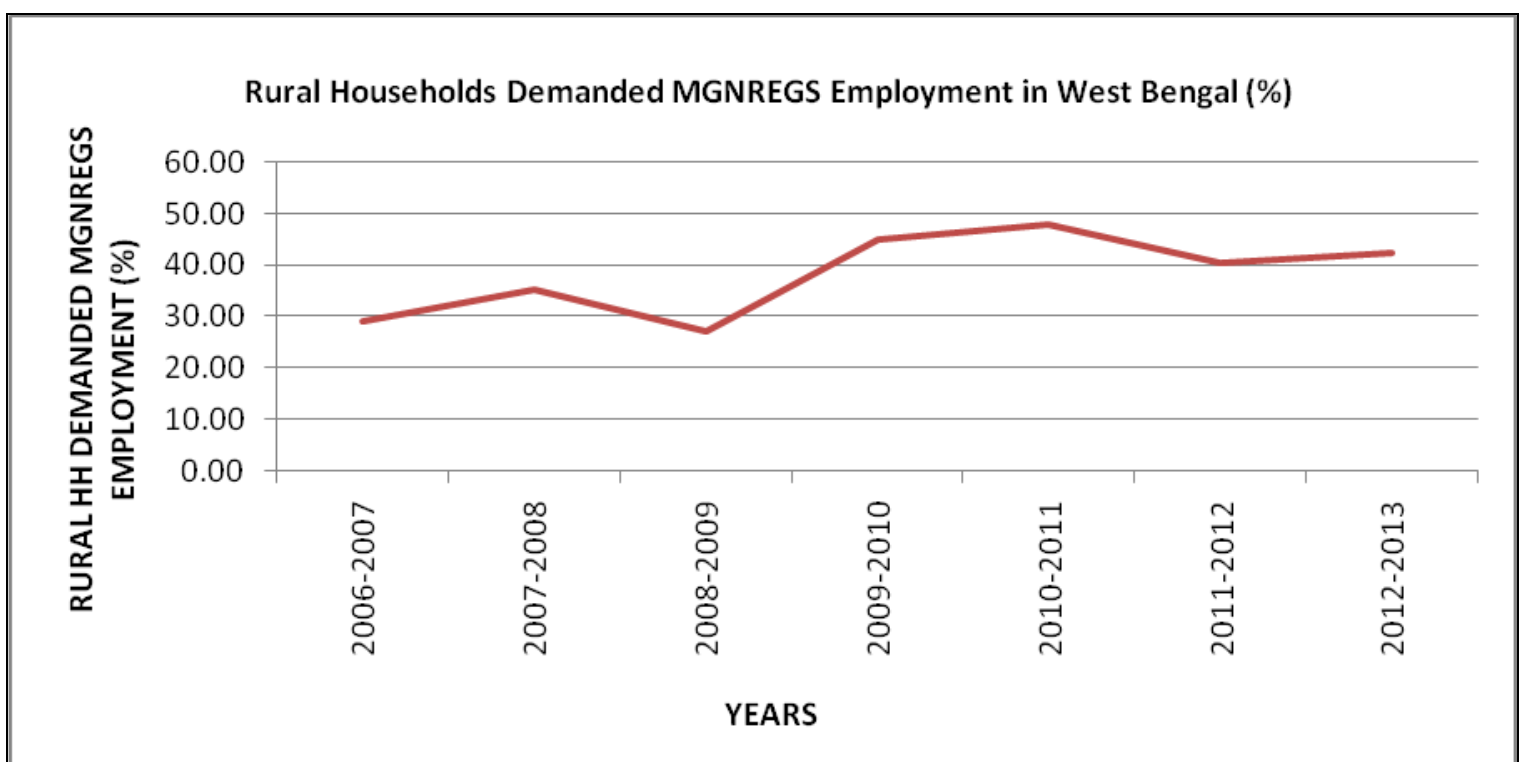

Table 2 depicts the demand trend of MGNREGS job on a temporal scale. It is seen that the temporal trend is fluctuating over years. Year 2011-2012 has noticed a rise over 40 percent. The decline in 2008-2009, as explained by Minister of State for Rural Development Pradeep Jain 'Aditya' is due to 'a myriad of factors external to the programme management.Such factors include available of alternative and remunerative employment opportunities outside MNREGA, rainfall pattern, prevailing unskilled wage rate in rural, semiurban and urban areas, better connectivity to semi-urban, peri-urban and urban areas'[1]. The most noticeable incident is the abrupt rise of demand in the corresponding year, i.e. 2012-2013 to $42.44 \%$ which is highest among all seven years. As MGNREGS is a demand-driven wage employment generating programme so the stability of demand is the key of the success of this scheme. This key is missing in temporal trend of employment demand. Stability of demand is expected keeping in view the economic condition of the rural West Bengal. National Health profile 2011 shows $28.8 \%$ of total rural population resides below poverty line of this state which is contradictory to the employment demand situation in West Bengal.

\section{MGNREGS: The Trend in Receive Demand Ratio}

The trend of receive-demand ratio in West Bengal is not as frustrating as demand trend. This ratio is more than $90 \%$ in all years. Year 2008-2009 shows $100 \%$ of receive demand ratio which gives an optimistic picture. This ratio is calculated by the following formulae:

Receive-Demand Ratio $=\frac{h h r}{h h d} * 100$

(Where,

hhr = Number of households received employment,

hhd $=$ Number of households demanded employment )

Though receive demand ratio shows moderately positive correlation of receive demand ratio( $\left(\mathrm{r}^{2}=0.69\right)$ with years but it worth to mention that the high receive demand ratio does not necessarily means successful

\footnotetext{
${ }^{1}$ Based on 2001 Census of India

${ }^{2}$ Based on 2011 Census of India
} 
implementation of the scheme. This figure should be analysed keeping this fact in mind that it does not reflect the number of employment days; the household received only one employment day in whole financial year is eligible to be included in the category of households received MGNREGS job in the respective year. Still, this figure is optimistic as it reflects the administrative effort to mitigate the incident of job refusal across state. Proper response of the administration in considering the job demand is a good sign for future development, which is undoubtedly seen in the trend of receive demand ratio of West Bengal. On an average, 45.09lakh households got employment in last seven years against demand of the 45.59 lakh households. So, it can be stated that 7152 households per year have subjected to $100 \%$ job refusal on an average in West Bengal.

TABLE.3. TREND OF RECEIVE DEMAND RATIO OF MGNREGS JOB IN WEST BENGAL

\begin{tabular}{|c|c|c|c|}
\hline YEAR & $\begin{array}{c}\text { NO.OF HOUSEHOLDS } \\
\text { DEMANDED EMPLOYMENT }\end{array}$ & $\begin{array}{c}\text { NO. OF HOUSEHOLDS } \\
\text { RECEIVED EMPLOYMENT }\end{array}$ & $\begin{array}{l}\text { RECEIVE DEMAND } \\
\text { RATIO IN \% }\end{array}$ \\
\hline $2006-2007$ & 3235360 & 3083757 & 95.31 \\
\hline $2007-2008$ & 3919996 & 3843335 & 98.04 \\
\hline $2008-2009$ & 3025854 & 3025854 & 100.00 \\
\hline $2009-2010$ & 5034060 & 4994124 & 99.21 \\
\hline $2010-2011$ & 5348896 & 5319677 & 99.45 \\
\hline $2011-2012$ & 5532363 & 5516968 & 99.72 \\
\hline $2012-2013$ & 5822214 & 5784565 & 99.35 \\
\hline
\end{tabular}

Source-www.nrega.nic.in

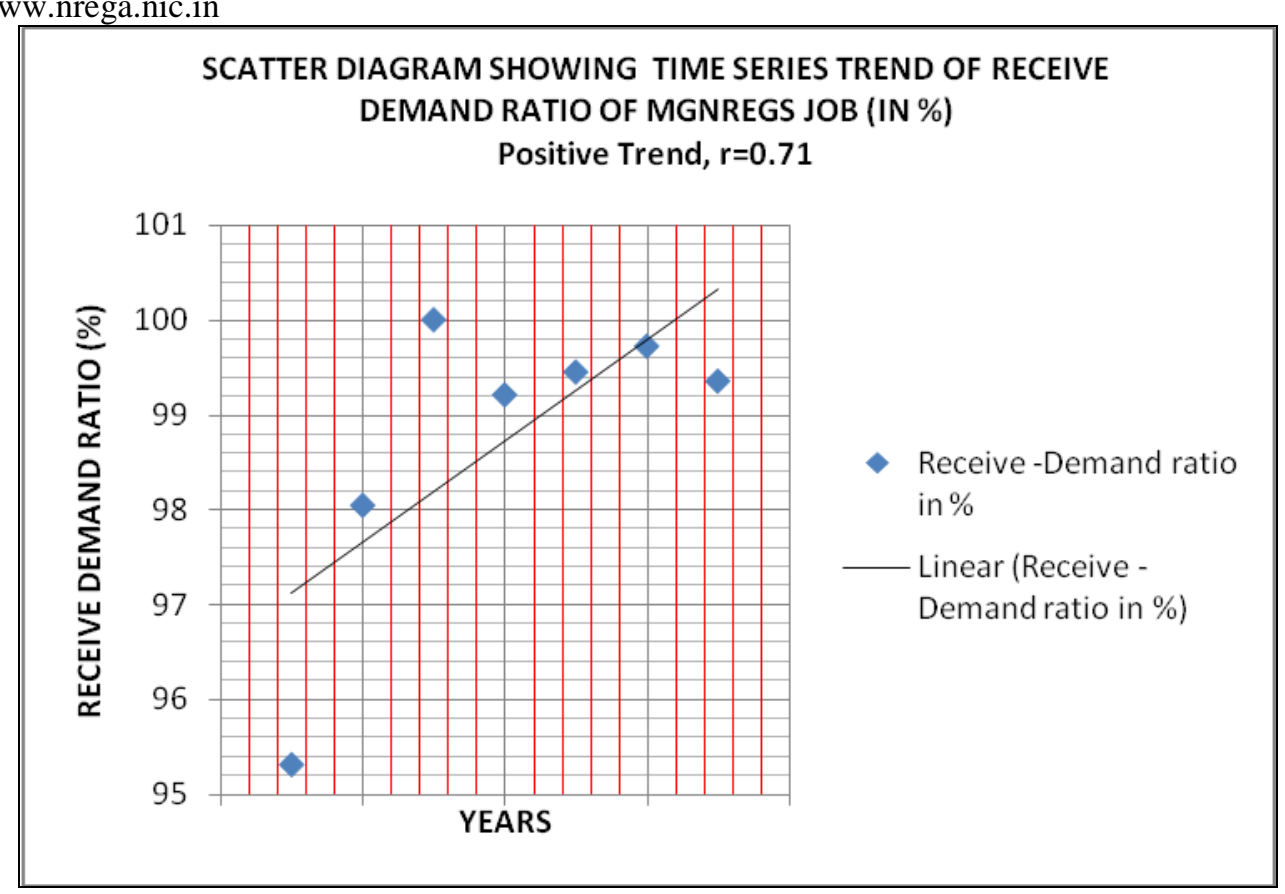

\section{Temporal Analysis Of Employment Generation Through Mgnregs In West Bengal}

The prime focus of MGNREGS implementation is employment generation based on rural demand. The study of employment generation is significant as it is directly related with the success of the scheme. Employment is measured in terms of persondays for MGNREGS. The trend of persondays generation shows increasing trend in terms of MGNREGS implementation over years. With a mean of 1173.11 lakhs total persondays in last seven years, the graph shows rise in the contribution of men and women. Line graph showing the temporal trend exhibits two interesting facts, a) both men and women employment days has increased with time, but contribution of women has remained always lower than that of the contribution of men and b) in last financial year i.e.in 2012-2013, the gap between men and women employment took a significant look. This is the highest gap of gender specific employment found since the implementation of the scheme after implemented all over West Bengal. 
Table: 4 .TEMPORAL ANALYSIS OF EMPLOYMENT GENERATION THROUGH MGNREGS IN WEST BENGAL

\begin{tabular}{|c|c|c|c|}
\hline YEAR & $\begin{array}{c}\text { TOTAL PERSON DAYS } \\
\text { GENERATED } \\
(\text { LAKH })\end{array}$ & $\begin{array}{c}\text { PERSONDAYS } \\
\text { GENERATED BY } \\
\text { WOMEN (LAKH) }\end{array}$ & $\begin{array}{c}\text { PERSONDAYS } \\
\text { GENERATED BY MEN } \\
(\text { LAKH) }\end{array}$ \\
\hline $2006-2007$ & 440.08 & 80.46 & 359.62 \\
\hline $2007-2008$ & 968.8 & 164.63 & 804.17 \\
\hline $2008-2009$ & 786.61 & 208.66 & 577.95 \\
\hline $2009-2010$ & 1096.52 & 316.87 & 779.65 \\
\hline $2010-2011$ & 1434.76 & 453.84 & 980.92 \\
\hline $2011-2012$ & 1495.937 & 486.23 & 1009.707 \\
\hline $2012-2013$ & 1989.05 & 669.50 & 1319.55 \\
\hline MEAN & 1173.11 & 340.03 & 833.08 \\
\hline MEAN ANNUAL & 50.28 & 104.58 & 38.13 \\
\hline
\end{tabular}

Source-www.nrega.nic.in

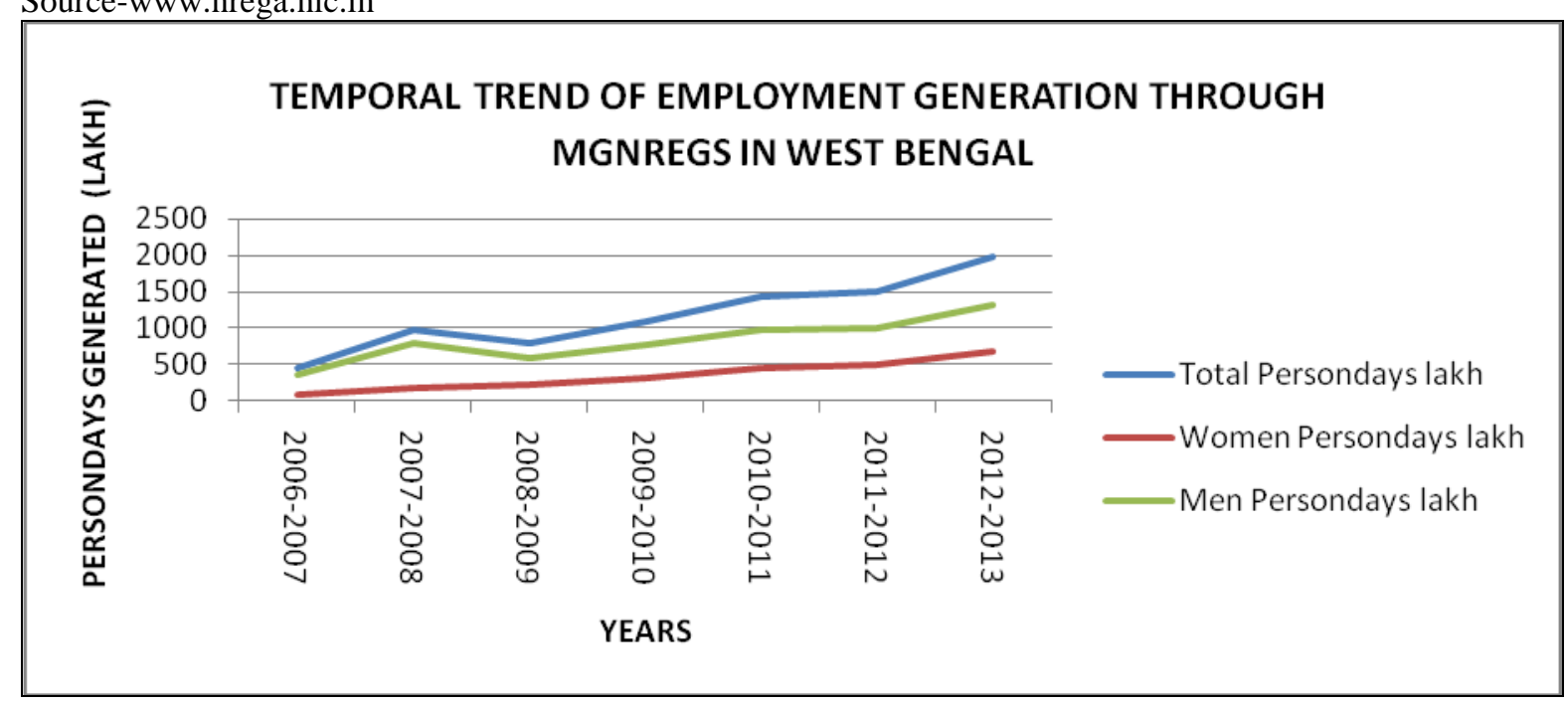

To understand the actual nature of gender specific employment generation, correlation coefficient is calculated following Pearson's measure. Here total person days are taken as variable $\mathrm{X}$ and person days generated by women are taken as variable $\mathrm{Y}$. The result shows not much difference in $\mathrm{r}$ value. It is 0.99 (highly positive) in the case of men and 0.98 (highly positive) in the case of women. The difference in the positive trend does not reflectthe real situation of dominance of male labour in MGNREGS worksites in the state.

The data set shows mean annual growth rate of $50.28 \%$ for total employment,38.13\% for women employment and $104.58 \%$ for men employment under MGNREGS. The high difference in growth rate is supporting the fact that women employment has not increased as much in comparison with men's employment. The general trend of higheremployment is found in the case of men that that of women, another significant characteristic of this growth rate is the annual growth rate for men is even higher than that of the annual growth rate for total employment. 


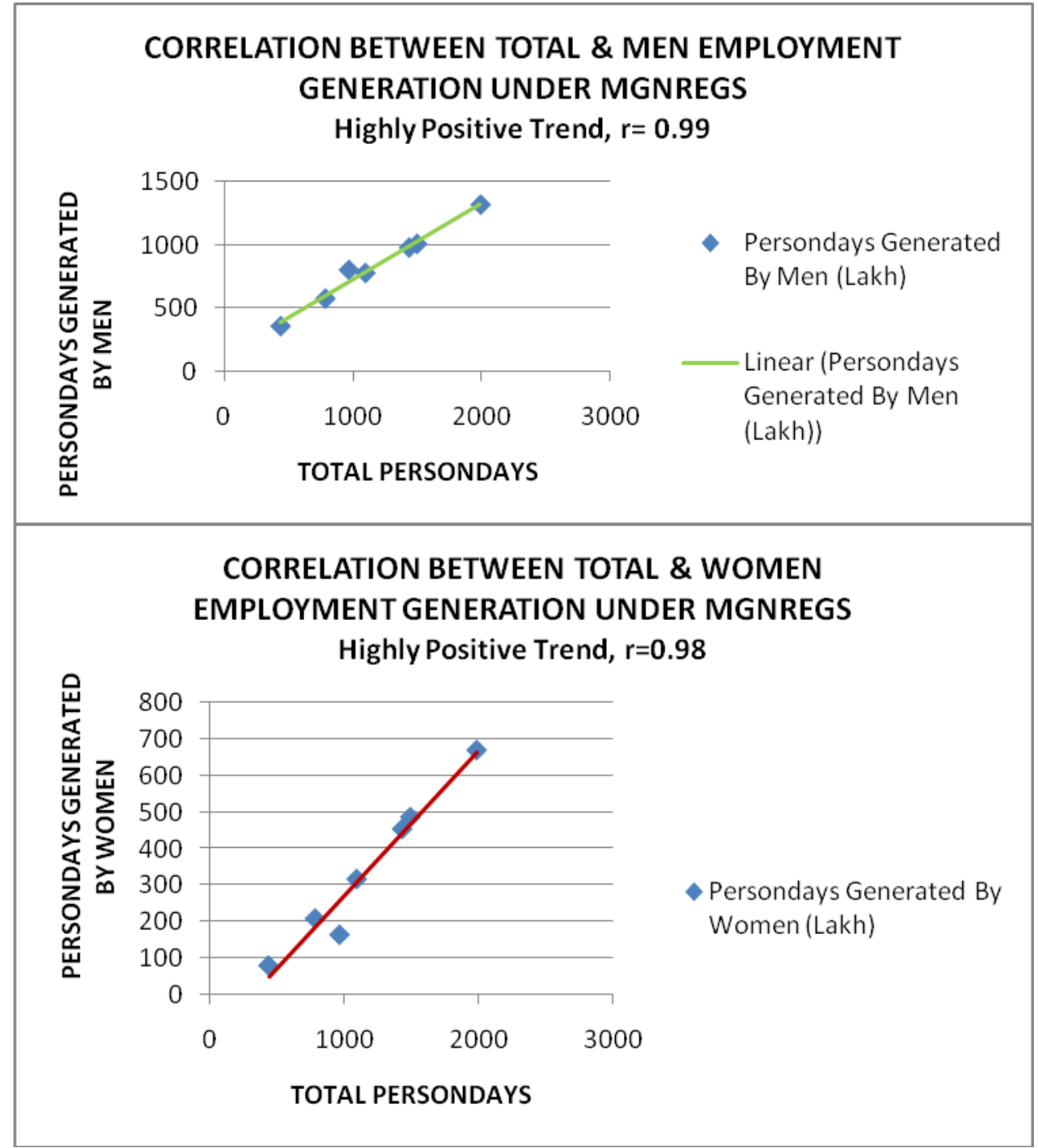

\section{Discussion: Critical Issues}

The rapid expansion of MGNREGS work in past seven years has created new possibilities of social protection reflected in the above discussion. These types of changes advocate transformations in rural society. The self targeting nature of MGNREGS has got huge response in the state. The study finds some issues regarding implementation of MGNREGS in West Bengal. These are:

a) The measurement of employment through secondary data is difficult as there is no measure given on gender specific number of workers.

b) Temporal analysis reflects that there is general increase of employment demand but the trend of demand is fluctuating inspiteof prevailing unemployment situation in West Bengal.According to Chauhan (2013)[3] "the fact that states with significant Below Poverty Line (BPL) population like Bihar and West Bengal recorded even lesser usage of the scheme than the national average. The committee blamed "bottlenecks" in implementation of MG-NREGA such as delay in wage payment and slow execution of projects by gram panchayats".

c) The dearth of data regarding intra household job distribution makes it difficult to understand actual situation of job distribution across time and gender.

d) Women participation in MGNREGS is comparatively less than that of men. Women participation is necessary for the betterment of their situation. The role of MGNREGS, as put by Pradhan (2012)[2]"In rural areas, more than 90 per cent of woman workers are farm labourers or cultivators and a substantial part of their work is unpaid since they work in their farms. However, NREGA has changed this".

\section{Concluding Observations}

The observations of the study may be of interest of Indian policy makers, as this paper provides a detailed attempt to find out the temporal variations of employment related aspects in the state. Though 
temporal progress is seen in terms of MGNREGS implementation is found in West Bengal but the goal of 100 days of promised employment is far to achieve. This is one of the major drawbacks of the scheme implementation in west Bengal. It is also suggested that apart from mere fulfilment of the one third of women beneficiaries, the emphasis should be given on fulfilment of promised employment days together with encouragement of women to bring them in the workforce. More participation will enhance more employment; more employment will create or modify more rural assets, will generate more income and in turn, generate more savings. These outcomes like employment, savings, income and rural assets will lead to a sustainable village economy in West Bengal. This paper is limited within the boundary of temporal analysis, keeping the factors of variations as constant for entire state. The regional heterogeneity keeps the door open need for further discussion and study carried on micro levels.

\section{References}

[1] 'No decline in demand, popularity of MGNREGA, asserts centre', Reported by IBN Live India on 12.11.2013.

[2] Chauhan ,C. 'NREGA demand falls drastically, activists blame sloppy implementation' Hindustan Times New Delhi, August 24, 2013

[3] Pradhan, S. 'The NREGA and Rural Women: Employment Opportunities and Challenges'Presentedin International Conference on: 'Inclusive and Sustainable Growth (Role of Industries, Government and Civil Societies', 4-6 Oct 2012, Organized by IMT \& BAIF. 